DOI: $10.17951 /$ artes.2018.3.95-102

JAGODA KRYG

Uniwersytet Jagielloński

jagoda.kryg@gmail.com

\title{
Księga jako dzieło totalne. Od Mallarmégo do Pereca
}

Book as a Total Work of Art. From Mallarme to Perec

\begin{abstract}
Streszczenie: Artykuł stanowi próbę przyjrzenia się literackiej koncepcji „Księgi” jako dzieła totalnego. Autorka analizuje w pierwszej kolejności teorię Stéphana Mallarmégo, dla którego Księga jako „całkowita ekspansja litery” była jednocześnie dziełem literackim i materialnym, dążącym do uchwycenia stale wymykającej się rzeczywistości i całościowego zamknięcia w sobie wszechświata. Skazane na niepowodzenie nieustanne dążenie do materialnej realizacji potencjału nieskończoności pozwalają uznać Księgę za projekt, który w rzeczywistości nigdy nie miał zostać zrealizowany i istniał w świadomości autora jako swoisty mit literacki. W podobny sposób możemy analizować dzieła Georges’a Pereca, który przez figurę wyliczenia czy też nieustanną obsesję katalogowania i klasyfikacji, również zmierzał do całościowego objęcia rzeczywistości za pomocą literatury. Jak dowodzi autorka, obydwu pisarzy łączy właśnie chęć stworzenia dzieła idealnego, którego paradoks polega na tym, że za cel stawia sobie ono zamknięcie w dziele tego, co nieskończone i nazwaniu tego, co niepoznane.
\end{abstract}

Słowa kluczowe: Księga, dzieło totalne, Mallarme, Perec

Bez wątpienia Księga, czyli „całkowita ekspansja litery”, jak pisał Stéphane Mallarmé w eseju pod tytułem Kryzys wiersza ${ }^{1}$, funkcjonuje po dziś dzień jako jeden z najważniejszych mitów literackich, zaraz obok mitu języka idealnego, zdolnego zastąpić wszystkie inne. Ów charakter mityczny wiąże się z faktem, że Księga, jako przedmiot materialny, miała być próbą objęcia wszechświata, pokazaniem, że może on zostać w niej całościowo zamknięty, ale jednocześnie, jako przedmiot idealny, sama miała ten wszechświat kreować za pomocą słowa, obrazu, materii i dźwięku sprzężonych w jednym znaczeniu.

1 S. Mallarmé, Kryzys wiersza, [w:] tegoż, Wybór poezji, przeł. A. Ważyk, Warszawa 1980, s. 89. 
W koncepcji Mallarmégo Księga nie była tylko przedmiotem materialnym, choć i na ten temat autor pisał wiele, wskazując choćby dokładną liczbę jej woluminów i stron. Niemniej ważną rolę odgrywał jej aspekt performatywny. Estetyka Księgi miała bowiem wyrażać się, między innymi, przez narzędzia, jakimi dysponuje teatr. W rzeczywistości wszystkie jej elementy, jak zauważa Mary Shaw, miały sobie nawzajem odpowiadać, tworząc spójną logiczną strukturęé: liczba i długość przedstawień była ściśle określona, podobnie jak liczba oraz rozmieszczenie widzów, którzy mieli uczestniczyć w głośnej lekturze. Mallarmé przewidywał nawet pięcioletnie przedstawianie Księgi, co miało odpowiadać symbolicznie jej pięciu tomom. Jednak w rzeczywistości ostatnia część nigdy nie miała powstać, podobnie jak piąty rok przedstawienia był „rokiem odpoczynku”. Co więcej, zgodnie w koncepcją autora, na każdy rok zaplanowane były dokładnie cztery, dziesięć lub dwadzieścia podwójnych „seansów”, tak by ich liczba zawsze stanowiła wielokrotność cyfr cztery lub pięć, co było nawiązaniem do religijnej praktyki chrześcijańskiej obchodzenia Roku Jubileuszowego dokładnie co 25 lat. Zgodnie z tą tradycją na każde stulecie przypadają cztery tak zwane Lata Święte, zaś kolejny, piąty Święty Rok jest swoistym wprowadzeniem w nowe stulecie. Na podobnej symbolice liczb opierała się właśnie Mallarméańska Księga, licząca potencjalnie cztery tomy oraz jeden nieistniejący, a także jej rytualne odczytania, zaplanowane tak, by ich liczba zawsze była wariacją cyfr cztery lub pięć.

Mallarmé w listach, notatkach czy artykułach niejednokrotnie określał Księgę właśnie mianem teatru, wypływającego z połączenia sztuki i nauki oraz opierającego się na nowego rodzaju języku. Język Księgi, jak wskazywał autor, miał zostać pozbawiony swej prymarnej funkcji komunikacyjnej, zaś słowa, niezależne od swego pierwotnego znaczenia - wyrażać przy pomocy czystych dźwięków i zmiany intonacji to, co do tej pory w literaturze było niewyrażalne. Mallarmé przeciwstawiał ponadto niedoskonały język codzienny, obarczony ładunkiem referencjalnym, czystemu i „zwieszonemu w nicości” językowi poezji, który ustanawiał nową zależność między znaczeniem a dźwiękiem. Pojmowanie języka nie przez pryzmat jego funkcji denotatywnej, lecz jako źródła oderwanych od siebie brzmień, zostało skądinąd przejęte na początku XX wieku przez ruchy awangardowe, między innymi przez dadaistów, których celem także było oswobodzenie go z przymusu wyrażania konkretnej treści i docenienie piękna samego znaczącego, oddziałującego swą materialnością i dźwiękiem. Totalność wielkiego dzieła Mallarmégo budowana jest zatem na wielu poziomach. Księga miała być $\mathrm{z}$ jednej strony materialnym obiektem, stworzonym w każdym najmniejszym

2 M. Shaw, Apocalypse et modernisme : le Livre de la fin, „Revue des sciences humaines” 1994, nr 4, s. 37. 
szczególe przez swego autora. Jednocześnie, choć zamknięta w tradycyjnym woluminie, odwoływała się do teatralnego misterium, jedynej w swoim rodzaju symfonii dźwięków, znaków i obrazów. Stosując podział wprowadzony przez Gottolda Ephraima Lessinga, moglibyśmy natomiast stwierdzić, że byłaby ona również dziełem czasowym i przestrzennym.

Jak trafnie zauważa Sarah Roberts, pomimo że Mallarmé poświęcał się projektowi Księgi niemal przez całe swoje życie, nieustannie pisząc o niej i sporządzając jej projekty, pojmował ją raczej jako ideał, który może zostać zrealizowany jedynie w jakiejś niewielkiej części, co możemy zauważyć w jednym z jego listów do Paula Verlaine'a:

Być może uda mi się, nie zrealizować całość [...], ale pokazać jakiś ukończony fragment, sprawić, by błyszczał wspaniale w promieniach autentyczności, wskazując całą resztę, na którą nie starczy nawet jedno życie. Udowodnić dokończonymi częściami, że ta książka istnieje i że poznałem to, czego nie zdołam ukończyćs ${ }^{3}$.

A zatem Mallarmé wydaje się postrzegać Księgę raczej jako przeżywaną nieustannie rzeczywistość, dzieło idealne, którego całościowe objęcie i utrwalenie nigdy nie będzie możliwe. Zaś fakt, że autor nie zrealizował tego projektu nie wynika z jego przedwczesnej śmierci - jak sądzą niektórzy - lecz z tego, że koncepcja Księgi od samego początku istnienia opierała się na pięknie samej potencjalności, ostateczności sensu i idei dzieła jako skończonej, zamykającej w sobie wszechświat całości. Z tego powodu Jean-Paul Sartre nazywa Mallarmégo "smutnym mistyfikatorem”, zauważając, że „stworzył on i podtrzymał wśród swych przyjaciół i uczniów iluzję wielkiego dzieła, w którym nagle rozpłynąłby się świat”4. Jak dodaje Sartre, „[Mallarmé] twierdził, że się do tego przygotowuje.

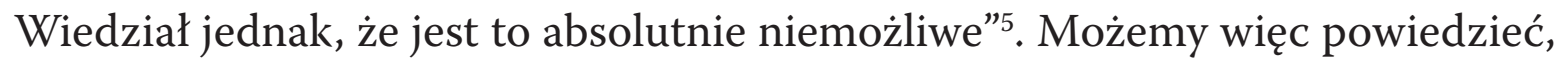
że Księga istniała i istnieje właśnie dzięki wyobrażeniu o niej. Paradoksalnie, zrealizowanie jej idei stanowiłoby pewne ostateczne domknięcie, byłoby negacją owej potencjalności i niosłoby za sobą swoisty koniec - nie tylko literatury, ale i świata. Jak twierdzi Shaw, realizacja Księgi może być właśnie odczytywana jako zwiastun apokalipsy. Co ciekawe, również sam Mallarmé wielokrotnie nawiązywał w swych notatkach na temat Księgi do wizji końca świata. Podążając za interpretacją Shaw, możemy stwierdzić jednak, że Księga, tak jak pojmował ją

3 S. Mallarmé, Mallarmé Stéphane, Autobiographie: Lettre à Verlaine, Caen 1991, s. 15. O ile nie zaznaczono inaczej, przekład z języka francuskiego autorstwa J. Kryg.

${ }^{4}$ J-P. Sartre, Mallarmé. La lucidité et sa face d’ombre, Paris 1986, s. 191.

5 Tamże. 
Mallarmé, będzie istnieć w swym wyobrażeniu dopóty, dopóki pozostanie ona niezrealizowana, podobnie jak ideał, który pozostaje ideałem tylko wówczas, gdy jest nieosiągalny. W rzeczywistości możemy dokładać coraz to nowe części, wzbogacać ją o nowe fragmenty, lecz nigdy nie jesteśmy w stanie jej objąć ani wypełnić w całości. Wraz z upływem czasu Księga będzie stale się powiększać, wchłaniać coraz to nowe dźwięki, obrazy i skrawki rzeczywistości, lecz jednocześnie jej granice będą pozostawać rozmyte, a ona sama będzie wciąż oddalać się, pozostawać nieosiągalna, tym samym potwierdzając swoje potencjalne istnienie.

Warto przypomnieć, że Mallarmé był jednym z pierwszych autorów, którzy nie tylko zaczęli głośno mówić o książce właśnie jako o materialnym przedmiocie, ale też materialność tę praktycznie realizować. To, o czym autor pisał w licznych esejach i o czym opowiadał swym uczniom, zostało, jak powszechnie wiadomo, po części ukonkretnione w poemacie przestrzennym pod tytułem Rzut kośćmi nigdy nie zniesie przypadku. Tak ważny aspekt przestrzenno-materialny tego utworu, początkowo całkowicie zignorowany przez edytorów, został szczegółowo przeanalizowany między innymi przez Michela Butora, który zwrócił uwagę choćby na różnice wynikające z rozmieszczenia liter i wyrazów, rolę światła typograficznego czy krój pisma. W istocie, Rzut kośćmi stanowi jeden z tych przykładów dzieł literackich, o których nie sposób mówić, ignorując jego warstwę wizualną. Należy także zwrócić uwagę na fakt, że Rzut kośćmi był jednym z pierwszych dzieł, jakie zapoczątkowały tak zwaną rewolucję wizualną, dzięki której pojmowanie dzieła literackiego zaczęło powoli się zmieniać. W rezultacie język przestał być traktowany jedynie jako przezroczyste narzędzie używane tylko po to, by wyrazić jakiś sens: sam w końcu mógł stać się sensem, przyciągając na siebie całą uwagę czytelnika, zafascynowanego, pomijanym dotąd, bogactwem jego dźwięków, kolorów i kształtów.

Uwagi Mallarmégo, dotyczące materialnego aspektu dzieła, związanego z układem typograficznym strony, właściwym doborem czcionki czy krojem liter, były jednak nie tylko realizowane pod względem praktycznym przez poetów i pisarzy, ale stanowiły też swego rodzaju początek głębszej refleksji o charakterze teoretyczno-literackim. Do muzyczności Księgi, której tak wiele uwagi poświęcił autor, nawiązywał choćby Paul Claudel, zauważając ścisły związek między słowem a jego graficzną realizacją na stronie. Claudel porównywał tę relację do swoistej symfonii, która rozbrzmiewa, gdy czytelnik przewraca kolejne strony tekstu, przyglądając się temu, jak sens wydobywa się z materialności poszczególnych znaków i liter. Natomiast wspomniany już wcześniej Butor w eseju Ksiażka jako przedmiot uznaje Rzut kośćmi za przykład doskonałego wykorzystania potencjału, jaki oferuje typografia. Autor zauważa cztery główne zasady, którymi kierował się Mallarmé tworząc to, co Butor nazwał „typografią 
ekspresywną". Pierwsza z tych zasad była związana z wielkością czcionki, uzależnioną od tego, jak głośno miały zostać odczytane konkretne słowa poematu. Druga określała światło typograficzne odpowiadające momentom ciszy. Trzecia i czwarta odwoływały się zaś do odpowiedniej intonacji głosu, wynikającej z tego, czy słowa umieszczone są na dole czy na górze strony i czy zapisane są kursywą, czy antykwą. Butor w swym eseju nie skupia się jednak wyłącznie na poemacie Mallarmégo, lecz w swych rozważaniach teoretycznoliterackich analizuje także możliwości, jakie oferuje pisarzowi cała książka, rozumiana jako materialny wolumen. Autor zauważa, między innymi, związek sensotwórczy, jaki powinien wytworzyć się pomiędzy układem typograficznym a samym tekstem. Przykładowo, każda linijka tekstu powinna według niego wyrażać określoną jednostkę sensu, po której następuje „moment ciszy”, czyli czas, gdy wzrok czytelnika wędruje z powrotem do lewej strony. Butor, odwołując się też do prozy Sterne'a i Rabelais'go, bodaj pierwszy raz w tak szczegółowy sposób omawia możliwości, jakie daje właśnie sama strona tekstu, na której litery czy znaki mogą być zapisane na wiele różnych sposobów: od lewej do prawej, od prawej do lewej czy też z góry na dól. Co ciekawe, autor mówi to, nad czym niemal każdy czytelnik przechodzi podczas lektury do porządku dziennego, nie zastanawiając się tak naprawdę, jaka jest potencjalna relacja między tekstem a jego rozmieszczeniem, kształtem czy towarzyszącymi mu ilustracjami. Nie bez przyczyny uznał on właśnie Sterne’a za największego do tej pory artystę $\mathrm{w}$ dziedzinie budowy książkowego wolumenu ${ }^{6}$. Warto też zauważyć, że Butor nie ograniczał się jedynie do rozważań teoretycznych, lecz sam starał się wykorzystywać potencjał wypływający z materialnego aspektu książki. Poza pisaniem prozy tradycyjnej tworzył także tak zwane livres -objets, czyli 'książki-przedmioty', które w wielu przypadkach czytelnik mógłby uznać raczej za dzieło sztuki wizualnej, niż tekst literacki. Książki-przedmioty tworzone, ale też, co ważniejsze, pisane przez Michela Butora czerpią niejednokrotnie z estetyki kolażu. Bardzo często książka w tym przypadku staje się więc terminem umownym, gdyż tekst może być przechowywany na dowolnym nośniku, niekoniecznie nawet zbliżonym rozmiarem czy kształtem do tradycyjnego wolumenu. Jednym z wcześniejszych dzieł Butora, w jakim autor sprzęga treść z materialną formą jest Mobile, którego tekst może budzić skojarzenia właśnie z Rzutem kośćmi Mallarmégo. Trudność klasyfikacji tego dzieła, które najczęściej uważa się za jeden z pierwszych hipertekstów, wynika z faktu, że autor zerwał w nim kategorycznie z klasyczną formą powieści (jakiej to do tamtej pory się poświęcał) na rzecz estetyki fragmentu, nielinearności i przestrzenności, dzięki którym to właśnie aspekt wizualny i materialny tekstu zostały wysunięte

${ }^{6}$ M. Butor, Le livre comme objets, [w:] tegoż, Répertoire II, Paris 1964, s. 122. 
na pierwszy plan. Podczas lektury, podobnie jak w Rzucie kośćmi, ważne staje się rozmieszczenie słów, światło typograficzne oraz relacja między tekstem pisanym antykwą a fragmentami reprezentowanymi przy pomocy kursywy, które odwołują się do różnych kontekstów. Mobile stanowi w istocie swego rodzaju dziennik podróży po Stanach Zjednoczonych, zaś rozwiązania formalne, jakimi posłużył się autor, miały wynikać z niejednorodności kraju, po którym podróżował. Ameryka, jak wyjaśniał Butor w jednym z wywiadów, wydawała mu się tak różnorodna, że przedstawienie jej jedynie przy pomocy tekstu linearnego okazało się niemożliwe. Najwłaściwszą dla pisarza techniką opisania Stanów Zjednoczonych stała się przede wszystkim lista - czyli stylistyczna kategoria wyliczenia. W przeciwieństwie do narracji, której podstawową jednostką jest zdanie, lista nie jest nigdy zakończona, daje wrażenie niedomknięcia, pewnej otwartości, gotowej wchłonąć w siebie zawsze nowe elementy. Warto także zauważyć, że kategoria listy funkcjonuje nierzadko w literaturze jako synonim swego rodzaju „totalności” i pojawia się bardzo często, gdy mamy do czynienia z dziełem, w którym autor postawił sobie za cel objęcie pewnej większej całości. Butor przyznał, że jedna z trudności wynikających z pisania o Stanach Zjednoczonych wiązała się właśnie z koniecznością zmierzenia się z długą formą literacką, która początkowo wydawała mu się najwłaściwsza, by zamknąć $\mathrm{w}$ tekście wrażenia z tak dużego i różnorodnego kraju. Wyliczenie umożliwiło mu jednak zmierzenie się z ogromem tego doświadczenia.

W podobny sposób lista funkcjonuje w twórczości Georges’a Pereca, dla którego sporządzanie inwentarzy i obsesyjne niemal katalogowanie stanowiło jedną ze strategii radzenia sobie z pustką. W przypadku Pereca pojęcie „wyczerpania” staje się kluczowe choćby wówczas, gdy autor postanawia wyliczyć z właściwą sobie precyzją wszystkie spożyte w ciągu roku pokarmy, wymienić przedmioty stojące na jego biurku czy kiedy stawia sobie za cel jak najdokładniejsze opisanie paryskiej ulicy, obserwując ją zza szyby kawiarni. Gromadzenie opisów i elementów rzeczywistości stanowiło dla Pereca przeciwieństwo pustki, z jaką musiał zmierzyć się po stracie rodziców, było trenowaniem pamięci w reakcji na brak wspomnień z dzieciństwa. Jak zauważył Umberto Eco, dzięki liście udaje nam się nie tylko wprowadzić pewien porządek, ale przede wszystkim pozwala nam ona uchwycić to, co nieodgadnione, pozwala zrozumieć nieskończoność ${ }^{7}$. Innymi słowy, jest kolejną próbą zawarcia w literaturze całej rzeczywistości.

7 S. Beyer, L. Gorris, Interview with Umberto Eco. We like list because we don't want to die, „Spiegel Online”, [dostęp online:] http://www.spiegel.de/international/zeitgeist/spiegel-interview-with-umberto-eco-we-like-lists-because-we-don-t-want-to-die-a-659577-2.html [data dostęp 01.04.2018]. 
Jednak bez względu na liczbę elementów czy długość wyliczenia, rzeczywistość ta nieustannie się wymyka, podobnie jak wszechświat, którego nie sposób zamknąć w Mallarméańskiej Księdze, „nawet gdyby miało się na to całe życie”. Perec, zdając sobie sprawę z ulotności wspomnień i niedoskonałości pamięci, traktuje listę jako jej przedłużenie i całkowicie zawierza materialnemu śladowi, jakim jest pismo. Nieuchwytną rzeczywistość autor dzieli na konkretne kategorie: w Życiu: instrukcji obstugi usiłuje opowiedzieć na blisko siedmiuset stronicach życie mieszkańców pewnej paryskiej kamienicy; w Próbie wyczerpania pewnego miejsca paryskiego ogranicza się do Placu Saint Sulpice - konkretnego wycinka miasta, sprawdzając, czy możliwe jest oddanie w tekście jego dynamiki, ogarnięcie nim jego całej złożoności; z kolei w eseju Odmiany przestrzeni Perec stawia sobie za cel właśnie wyczerpanie przestrzeni jako takiej, we wszystkich jej aspektach i szczegółach, rozpoczynając od najmniejszej, jaką dla pisarza jest kartka papieru, a kończąc na całym wszechświecie. Dzięki podziałowi na kategorie, każdy wycinek rzeczywistości staje się łatwiejszy do opanowania. Nagle kartka papieru wzięta pod lupę okazuje się powierzchnią, na której można pisać w linii pochyłej, pionowo, a nawet na marginesach. Daje się zauważyć, że każde dzieło Pereca, dążące do opisania jakiegoś wyimka otaczającego świata, może być traktowane jako swoisty mikrokosmos. Autor zauważył kiedyś w jednym z wywiadów, że nigdy nie napisał dwóch takich samych książek. W rzeczywistości jednak każde z jego dzieł staje się fragmentem większej całości, elementem listy, która stale dąży do niemożliwego wyczerpania.

Jak możemy zauważyć, zarówno w teoriach, jak i praktykach dwudziestowiecznych, książka staje się często synonimem totalności. Jako termin pojawia się często wówczas, gdy dzieło zaczyna wymykać się tradycyjnemu nazewnictwu, a pojęcia takie jak „powieść” czy „poemat” nie oddają efektu pracy autora tak, jak ma to miejsce choćby w przypadku Mobile Butora czy Odmian przestrzeni Pereca. Mallarméańska koncepcja Księgi, jaką autor zaczął realizować w Rzucie kośćmi, stała się w literaturze pewnego rodzaju mitem, do którego odwoływało się (i odwołuje nadal) wielu artystów, spośród których kilku zostało wspomnianych powyżej. Księga dąży do tego, by obraz, znak i dźwięk połączyły się w jednym znaczeniu, lecz jednocześnie wychodzi poza samą literaturę, chcąc stać się inkarnacją wszystkiego, co istnieje. Znamienne jest jednak, że Księga, choć nieustannie zmierza do swej materializacji, nigdy nie może zostać zrealizowana raz na zawsze. Swą pełnię osiąga jedynie we fragmentach, materialnie zapisanych i utrwalonych odpryskach rzeczywistości. Jak zauważył w Przestrzeni literackiej Maurice Blanchot, dzieło jest czymś, co nigdy nie jest skończone, czymś, co dzieje się bezustannie. Podobnie możemy powiedzieć o niedomkniętej liście i nieukończonej Księdze. Wizja totalności, całościowego objęcia świata 
od wieków jest marzeniem artystów. Paradoksalnie jednak literatura może istnieć dopóty, dopóki nikt nie postawi kropki na końcu listy, ideał nie zostanie osiągnięty, a Księga nadal będzie się oddalała na horyzoncie literackich marzeń.

\section{Bibliografia}

1. Beyer S., Gorris L., Interview with Umberto Eco. We like list because we don't want to die, „Spiegel Online” 2009, [online:] http://www.spiegel.de/international/zeitgeist/spiegel-interview-with-umberto-eco-we-like-lists-because-we-don-t-wantto-die-a-659577-2.html [data dostępu 01.09.2017].

2. Blanchot M., Przestrzeń literacka, przeł. T. Falkowski, Warszawa 2016.

3. Butor M., Le livre comme objets, [w:] tegoż, Répertoire II, Paris 1964, s. 104-123.

4. Mallarmé S., Kryzys wiersza, [w:] tegoż, Wybór poezji, przeł. A. Ważyk, Warszawa 1980.

5. Mallarmé S., Autobiographie : Lettre à Verlaine, Caen 1991.

6. Sartre J.-P., Mallarmé. La lucidité et sa face d'ombre, Paris 1986.

7. Shaw M., Apocalypse et modernisme: le Livre de la fin, „Revue des sciences humaines” 1994, nr 4, s. 35-46.

Summary: The article is an attempt to look at the literary concept of the "Book" as a total work of art. The author first analyses the theory of Stéphane Mallarmé, for whom the Book as a "total expansion of the letter" was both a literary and material work, seeking to capture the constantly escaping reality. The endless pursuit of the material realization of the potential of infinity allow us to consider the Book a project that in reality was never intended to be realized and existed in the author's consciousness as a kind of literary myth. In a similar way, we can analyse the works of Georges Perec, who, through the figure of enumeration or the constant obsession of cataloging and classification, also aimed to embrace reality as a whole through literature. As the author argues, what both writers have in common is the desire to create an ideal work of art, whose paradox consists in the fact that it aims to embody what is infinite and to name the what is still unknown.

Key words: Mallarmé, Book, total work of art, Perec 